\title{
Integrasi Pendidikan Karakter Berbasis Qurani Dan Kearifan Lokal Bugis
}

\author{
Yusuf \\ UIN Alauddin Makasar \\ yy2459487@gmail.com
}

\begin{abstract}
This article studies about education character bases on the quranic values and local wisdom, particularly Bugis culture. Conceptually, the education must be able to build character through internalization of religious values and local wisdom. First, self control by religious approach is to empower religious values as an early prevention to corruption and manipulation. Second, to empower local wisdom values, in this case Bugis culture, which are relevant to Islamic doctrine. Both culture and Islamic teach universal truths such as honesty, integrity, truth, and goodness. Character education through internalization of core values must be in all education activities, including planning, process, and its evaluation. Integration of cognitive, affective, psychomotor aspects in all education process can build multiple intelligences. Integration of universal values of religion and core values of culture aims at preparing leaders who have a good character.
\end{abstract}

Keywords: Education, religion, value, local wisdom, character.

\section{A. Pendahuluan}

Potret buram prilaku sebagian aparatur Negara masalah utamanya adalah kaum elite yang sejatinya menjadi panutan, justru mereka adakalanya melakukan perbuatan tidak terpuji seperti korupsi, penyalahgunaan wewenang, dan jabatan. Pendidikan di Indonesia telah gagal mempersiapkan sumber daya sebagai kader-kader pemimpin yang memiliki integritas yang baik. Pendidikan belum mampu menginternalisasikan nilai-nilai utama ke dalam proses nurani peserta didik. Sistem Ujian Nasional yang diharapkan menjadi tolok ukur menentukan kualitas hasil proses pendidikan, justru seringkali menampilkan berbagai kecurangan. Pendidikan agama (termasuk pendidikan Islam) ${ }^{1}$ yang

\footnotetext{
${ }^{1}$ Wahyu Pramudya, "Pluralitas Agama: Tantangan Baru bagi Pendidikan Keagamaan di Indonesia, Veritas: Jurnal Teologi dan Pelayanan, Vol. 6, No. 2, Oktober 2005, h. 282.
} 
berbasis nilai tidak berjalan secara efektif, bahkan mengalami disfungsi. Fakta itu telah menjadi kegelisahan banyak kalangan. ${ }^{2}$

Persaingan yang kejam juga menimpa kalangan kaum terdidik terutama persaingan jabatan. Paradigma pendidikan kita kadang-kadang menekankan kompetisi, sehingga bukan hanya kompetisi yang sehat muncul, melainkan juga persaingan yang tidak sehat dan kezaliman. Arogansi dan gensi intelektual juga menimpa kaum terdidik. Karena "paradigama kompetisi" terlalu kuat mempengaruhi cara pandangnya, sehingga perlu diimbangi "paradigma kolaborasi” agar tercipta sinergi". 3 Dalam keadaan begitu, beberapa kalangan mencoba menawarkan solusi perlunya mengembalikan pendidikan pada nilai-nilai berbasis agama dan keluhuran nilai-nilai budaya. Yang pertama bersumber dari petunjuk kitab suci dan yang kedua bersumber dari nilai kearifan lokal.

\section{B. Kajian Pustaka}

Dalam perspektif Alquran, pendidikan sejatinya merupakan pembinaan manusia secara utuh, sehingga mampu menjalankan fungsinya sebagai hamba Allah dan khalifah-Nya guna membangun dunia ini sesuai dengan konsep yang ditetapkan Allah. Jika hal ini bisa mengejawantah dalam kenyataan maka umat Islam akan mampu mengimplementasikan ajaran Islam secara kaffah

\footnotetext{
2 Bandingkan Azhar Arsyad, "Universitas Islam: Integrasi dan Interkoneksitas Sains dan Ilmu Agama Menuju Peradaban Islam Universal” Junal Tsaqâfah, Jurnal Ilmu Pengetahuan dan Kebudayaan Islam, Institut Studi Islam Darussalam (ISID) Pondok Modern Darussalam Gontor, Indonesia, Vol. 2. No. 2, 2006, h. 427.

${ }^{3}$ Keterbatasan ilmu sejatinya menyadarkan para ilmuwan bahwa ilmu tidak pernah final dan setiap orang memiliki cirri khas. Hal sebagaimana diilustrasikan Alquran dalam Qs. al-Kahfi/18: 60-82. Ayat ini mengisahkan keterbatasan ilmu Nabi Musa a.s. dan Khidhr. Karakter ilmu Nabi Musa menonjol pada ilmu eksoterik (lahiriyah) sedangkan Khidhr mengetahui ilmu yang bersifat esoterik. Musa, meskipun ia seorang Nabi dan berasal dari kalangan Bani Israil yang terkenal cerdascerdas, namun Allah menyuruh untuk berguru kepada Khidhr mengenai ilmu-ilmu yang supra rasional itu, yaitu ilmu ladunni. Kisah-kisah memberikan petunjuk moral agar tidak muncul arogansi intelektual di kalangan ilmuwan,bahkan saling berkolaborasi dalam mengembangkan dirinya sekaligus menjadi teladan yang baik dengan sikap yang santun dan saling memuliakan. Hal ini telah diuraikan oleh penulis dalam salah satu buku. Lebih lanjut diuraikan Muhammad Yusuf, Tafsir AyatAyat Pendidikan dengan Metode Semi Tematik dan Tematik, (Makassar:Alauddin University Press, 2014), h. 28-66.
} 
(komprehensif dan paripuna). ${ }^{4}$ Akan tetapi, tidak jarang nilai-nilai luhur yang bersumber dari ajaran Islam dan budaya mengalami disfungsi dan tidak berdaya ketika berhadapan dengan tuntutan modernitas.

Modernitas merupakan anak kandung yang lahir dari rahim kreativitas akal budi manusia yang berkembang sesuai dengan tantangan kehidupan manusia. ${ }^{5}$ Seiring perkembangan zaman, tantangan, dan permasalahan juga muncul dengan aneka bentuknya, dan salah satu persoalan yang sangat krusial adalah hasil pendidikan Nasional yang mengecewakan, sebab prilaku sebagian pemimpin di Republik ini tidak mencerminkan prilaku terpuji. Nilai-nilai kejujuran - sebagai kebenaran universal -, tidak tertanam dalam kesadaran mereka dalam mengemban amanah publik. Nilai-nilai luhur ajaran agama dan nilai-nilai utama suatu budaya terluluh lantahkan oleh godaan materi. Keduanya kadang-kadang tidak mampu menjadi instrumen proteksi terhadap individu aparatur negara dari berbagai tindak pidana korupsi sehingga belum mampu mewujudkan tata kelola pemerintahan yang bersih dari praktik korupsi, kolusi, dan nepotisme .

Perbaikan karakter bangsa tidak cukup dengan kecerdasan kognitifintelektual semata, Perubahan (reformasi), itu diisyaratkan oleh Alquran

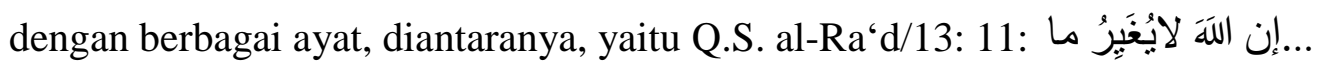
sesuatu kaum sehingga mereka merobah keadaan yang ada pada diri mereka sendiri ....". Ayat ini mengandung informasi yang amat mendasar. Pertama, pendidikan karakter bermula dari "sisi dalam" pada manusia (peserta didik)

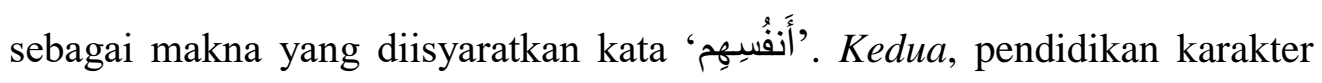
harus didukung oleh sebuah sistem yang melibatkan banyak elemen, bukan

\footnotetext{
${ }^{4}$ Muhammad Sayyid Sultan, Buhûts fì al-Tarbiyah fî al-Tarbiyah al-Islâmiyyah, (Kairo: Dâr al-Ma'ârif, 1979), h. 53.

5 Bandingkan dengan Amin Abdullah "Pendidikan Islam dan Tantangan Modernitas" Jurnal Pendidikan, (Makassar: Lentera Fakultas Tarbiyah IAIN Alauddin, 1998), h. 3.
} 


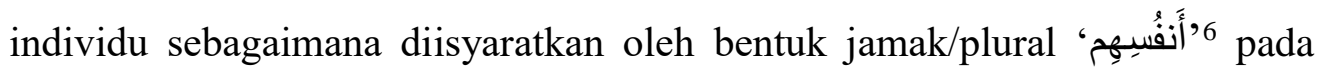
ayat di atas. Terma 'أَفُْسِِ (diri mereka sendiri) pada ayat tersebut menunjukkan 'sisi dalam' manusia yang meliputi idea-idea atau nilai-nilai yang terdapat dalam benaknya, serta diyakini kebenaran dan manfaatnya yang melahirkan tekad yang kuat untuk merealisirnya. Petunjuk Q.S. al-Ra'd/13: 11 di atas bahwa perubahan dimulai dengan pendidikan nilai dan internalisasinya yang pada gilirannya membentuk karakter dan prilaku yang diharapkan. Hal ini sejalan dengan petunjuk Alquran surah al-Tahrîm/66: 6, يَا أَيُهَا الذين أمنوا ... Hai orang-orang yang beriman, peliharalah dirimu dan keluargamu dari api neraka ...".

Pendidikan akan menjadi efektif apabila melalui keteladanan yang dimulai pada diri pendidik, kemudian orang-orang yang ada di bawah tanggung jawab sebagaimana isyarat kalimat قُو أَنْفَكُم و أهلِيكُم (pelihara dirimu dan keluargamu). Konsep pembentukan karakter ini merupakan nilai-nilai inti (core values) yang mesti ada adalah reformasi pendidikan. Perubahan sistem dan Undang-Undang atau peraturan dan kebijakan saja itu tidak cukup, karena manusialah yang menentukan, the man behind the gun. Berdasar pada pandangan tersebut, pendekatan kemanusiaan (human approach) dan pendekatan sistem (system approah) merupakan dua hal yang tidak bisa dipisahkan, bahkan harus berjalan secara simultan, sebab aparatur yang baik yang tidak didukung oleh sebuah sistem dan birokrasi yang baik, akibatnya tidak berjalan secara efektif. Demikian pula sistem yang baik tetapi tidak didukung oleh aparatur yang baik juga tidak bisa berjalan secara efektif. Sebaliknya, aparatur yang baik didukung sebuah sistem birokrasi yang baik, akan berjalan beriringan dengan baik, dan akan melahirkan budaya kerja yang baik dan sehat. Perbaikan hanya bisa terwujud secara efektif dengan perpaduan antara kualitas personal dan profesionalitas aparatur didukung oleh sebuah sistem yang baik. Internalisasi nilai-nilai agama dipandang sebagai upaya

${ }^{6}$ M. Quraish Shihab, "Pendidikan Nilai untuk Pembentukan Sikap dan Prilaku", dalam Jurnal Pendidikan, (Ujung Pandang: Lentera Fak. Tarbiyah IAIN Alauddin 1997), h. 32. 
menanamkan nilai-nilai agama sebagai instrumen kontrol terhadap prilaku aparatur dan setiap warga negara.

Inspektorat Kementerian Agama R.I. menyadari pentingnnya pengawasan dengan pendekatan agama (PPA) terhadap aparatur. PPA merupakan alternatif model pengawasan dini yang pendekatannya lebih menekankan pada pembedayaan nilai-nilai agama. Dalam PPA, terjalin hubungan antara manajemen pemerintahan dengan nilai-nilai ketuhanan yang disuarakan dari dalam hati nurani. Pendekatan ini dikembangkan untuk mendorong terbentuknya karakter dan jati diri aparatur negara melalui pemahaman dan internalisasi nilai-nilai agama, agar mampu menjalankan fungsi kontrol diri (self control) dalam rangka membangun pemerintahan dan budaya kerja yang baik dan bersih. ${ }^{7}$ Sebab, kerja dalam pandangan agama adalah ibadah sedangkan kejujuran dan amanah adalah wujud kekuatan iman yang bersumber dari hati nurani yang bersih.

PPA juga merupakan upaya mewujudkan kesadaran aparatur tentang arti penting pengawasan diri dalam rangka mewujudkan aparatur negara yang bersih, bermoral, dan profesional yang dibingkai dengan nilai-nilai spiritualkeagamaan. Dalam rangka mempersiapkan aparatur negara yang amanah, jujur, profesional, dan bertanggungjawab di masa mendatang maka pendidikan agama secara khsusus, dan pendidikan pada umumnya yang terdiri dari perencanaan, proses, dan evaluasinya tidak lagi hanya pada aspek kognitifteoretis yang menjadi fokus perhatian, tetapi yang mendesak adalah terbangunnya kesadaran individu peserta didik melalui internalisasi nilai-nilai agamanya. Pendekatan tersebut harus pula didukung oleh nilai-nilai budaya yang luhur dan sejalan dengan ajaran agama, agar keluhuran tersebut membudaya dalam setiap pikiran, perkataan, dan perbuataannya. Untuk mewujudkan hal tersebut, dibutuhkan pengenalan dan penggalian ulang terhadap nilai-nilai budaya yang utama untuk menopang pembinaan karakter yang utuh dan kuat dalam kepribadian peserta didik.

${ }^{7}$ Tim Penyusun, Mengembangkan Budaya Kerja Melalui Pengawasan dengan Pendekatan Agama, (Jakarta: Itjen Kementerian Agama RI., 2011), h. 3-4. 
Kearifan lokal $^{8}$ seringkali menjadi sesuatu yang dirindukan oleh kesadaran masyarakat dan pemerintah bahwa dalam menghadapi tantangan demokratisasi dan gelombang globalisasi dibutuhkan penggalian ulang terhadap nilai-nilai dan khazanah lokal yang sarat dengan nilai-nilai luhur. Nilai-nilai luhur tersebut merupakan cerminan budaya dan karakter masyarakat Sulawesi Selatan. Sejak dahulu kala, budaya masyarakat Sulawesi Selatan sudah tercatat di dalam literatur kuno orang Bugis-Makassar dengan istilah “Lontarak". Zaman pra Islam, Sulawesi Selatan yang sampai sekarang dapat diungkapkan melalui sumber-sumber tertulis, barulah dapat diungkapkan sekitar abad XIV M. hingga diterimanya Islam sebagai agama yang dianut oleh masyarakat pada awal abad XVII M. Dalam kurun waktu tersebut, sumber yang melukiskan keadaan masyarakat tersebut hanyalah Lontarak. ${ }^{9}$

Nilai-nilai dalam kebudayaan orang Bugis itu perlu diungkapkan dalam setiap gerak kehidupan orang Bugis dalam menghadapi setiap dinamika kehidupan yang penuh tantangan. Nilai-nilai itu diciptakan karena dimuliakan oleh para leluhur mereka sebagai peletak dasar masyarakat dan kebudayaan Bugis. Selanjutnya, dialihkan dari suatu generasi ke generasi. Dalam upaya mewariskannya, mereka menyampaikan dalam bentuk nasihat atau pesan serta petuah itu terdapat dalam lontarak-lontarak yang disebut pappanngaja dan paseng. ${ }^{10}$ Kebudayaan Bugis dapat ditelusuri dalam beberapa literatur, misalnya dalam "Nilai-Nilai Utama Kebudayaan Bugis". ${ }^{11}$ Kebudayaan orang

${ }^{8}$ Nilai-nilai kearifan budaya lokal yang dimaksud dalam tulisan ini adalah nilai-nilai kearifan budaya Bugis, yang tentu saja terdapat pada nilai-nilai budaya suku dan etnik lainnya. Dalam kajian Islam, kearifan lokal lebih dikenal dengan istilah al- 'urf. Al- 'Urf merupakan salah satu sumber hukum Islam, yakni menjadi pertimbangan dalam penetapan hukum, selama tidak bertentangan dengan prinsip-prinsip dasar al-Qur'an dan Sunnah. Nilai-nilai budaya dan tradisi yang sejalan dengan Islam dapat menjadi alat legalitas (hukum). Penggalian terhadap nilai-nilai budaya merupakan anjuran agama, sebab di dalamnya banyak ditemukan nilai-nilai luhur yang sejalan dengan Islam.

${ }^{9}$ Mattulada, Sulawesi Selatan Pra Islam dalam Bultetin Yaperna No. 12, tahun III., h. 76.

${ }^{10}$ A. Rahman Rahim, Nilai-Nilai Utama Kebudayaan Bugis, (Yogyakarta: Ombak, 2011), h. 66. Dikutip dari Prof. Drs. G.H.M. Riekerk "Lahirnya Kedatuan Tomanurung" (ceramah), Fakultas Hukum Universitas Hasanuddin Ujung Pandang, 13 Agustus 1969.

${ }^{11}$ A. Rahman Rahim, Nilai-Nilai Utama ...., h. 37-66. 
Bugis mempunyai nilai-nilai utama berupa kejujuran, kecendikiaan, kepatutan, keteguhan, usaha atau kerja keras.

Secara etimologis, lempu' berarti “lurus" yang merupakan antonim dari kata 'bengkok'. Penggunaan kata tersebut dalam berbagai konteksnya, berarti juga ikhlas, benar, baik atau adil. Misalnya, laleng malempu' artinya jalan yang lurus. Dengan demikian antonim kata-kata tersebut yaitu curang, culas, dusta, khianat, seleweng, buruk, tipu, aniaya, dan semacamnya. Kejujuran merupakan sumber amanah, sebab inti amanah itu adalah kejujuran dan tanggung jawab. ${ }^{12}$ Intergritas mesti dibangun dalam situasi yang tidak instan, bahkan harus dibangun dari pembiasaan, keteladanan, kontrol, dan pengendalian. Ini merupakan tugas pendidikan yang paling utama dan urgen sepanjang zaman. Kejujuran, disamping merupakan nilai budaya juga merupakan ajaran qurani yang sangat fundamental.

\section{Metode Penelitian}

Pendekatan yang digunakan penulis dalam penelitian ini adalah kualitatif deskriptif, dengan menggunakan pendekatan kualitatif deskriptif merupakan metode atau cara untuk mengadakan penelitian seperti halnya penelitian non eksperimen yang dari segi tujuannya akan diperoleh jenis atau tipe yang diambil. Pendekatan ini akan menghasilkan data deskriptif yaitu berusaha mengerti dan memahami suatu.

\section{Pembahsan}

Masyarakat Bugis mempunyai nilai budaya siri'. Secara etimologis siri' berarti malu, harga diri. Selain itu, ada pula yang dikenal dengan pesse yang berarti solidaritas, kebersamaan, rasa ibah, kasih sayang. Bagi masyarakat Bugis, siri' adalah suatu norma yang sangat dihormati, karena hal itu merupakan bukti bahwa seseorang dapat menjaga kesucian diri dan kehormatannya. Siri' sangat berkaitan dengan lempu'. Lempu' dan pacci merupakan ciri budaya yang khas selama mereka merawat nilai-nilai tersebut

${ }^{12}$ Dr. (HC) AG.H. Muh Sanusi Baco, Lc., Ketua Umum Majelis Ulama Indonesia Sulawesi Selatan, Taushiyah dalam rangka Diskusi tentang Sertifikasi Dai yang di Prakarsai oleh Pengurus NU Wilayah Sulsel, Makassar, 19 Maret 2015. 
dalam hidupnya. Kesucian merupakan ajaran yang paling utama. Di dalam ajaran Islam kesucian dalam berakidah dan bertauhid merupakan syarat pertama dikatakan seseorang masuk Islam, yakni menyatakan secara totalitas "tidak ada Tuhan selain Allah dan Muhammad adalah Rasu-Nya" yang merupakan komitmen lahir dan batin. Dalam fikih, kesucian dan kebersihan (thahârah) selalu menempati bab awal. Kesucian (paccing) - termasuk kesucian tekad dan perbuatan - tidak disangsikan lagi sebagai ajaran yang

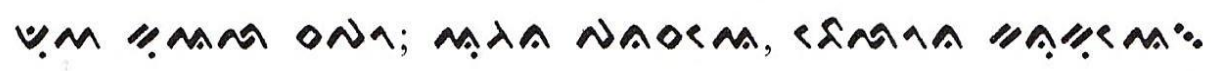

relevan dengan agama dan budaya. Dalam kaitan ini, syair orang Bugis menyebutkan: Duwa kuwala sappo; unganna panasae na belona kanukuel."Dua yang kujadikan pagar (pelindung diri dan kehormatan), yaitu bunga nangka dan hiasan kuku". ${ }^{13}$

Kata 'panasa' pada 'unganna panasae' yang sinonim dengan kata “lempu”. ${ }^{14}$ Bila diberi tekanan glottal stop (') pada suku kata terakhir menjadi lempu', maka kata itu berubah maknanya menjadi 'kejujuran'. Kata “belona kanukue”, digunakan untuk hiasan kuku (belo kanuku) yang disebut pacci. Kata pacci, bila mendapat tambahan bunyi "ng" pada akhir kata pacci menjadi paccing, maka kata itu berubah arti menjadi tidak ternoda, bersih, dan suci. Dengan demikian, "Duwai kuala sappo; unganna panasae, belona kanukue”

13 Dalam tradisi Bugis ada dua norma yang sangat dihormati selain dari norma-norma agama, yaitu siri' dan passe'. Siri" adalah "harga diri", yaitu suatu unsur yang sangat prinsipil dalam diri bagi orang Bugis. Bagi orang Bugis, siri' adalah jiwa mereka, harga diri mereka, dan martabat mereka. Oleh karena itu, untuk menegakkan dan membela 'siri' yang dianggap tercemar atau dicemarkan oleh orang lain, maka orang Bugis akan bersedia mengorbankan apa saja, termasuk jiwanya yang paling berharga demi tegaknya siri' dalam kehidupan mereka. Hamid Abdullah, Manusia Bugis-Makassar: Suatu Tinjauan Historis terhadap Pola Tingkah Laku dan Pandangan Hidup Bugis-Makassar (Jakarta: Inti Dayu, 1985), h. 37. Sementara passe adalah rasa solidaritas sesama orang Bugis, yaitu suatu nilai dimana ikut merasakan penderitaan orang lain dengan perasaan haru (empati) yang mendalam terhadap sesama. Christian Pelras, Manusia Bugis, Terj. Abdul Rahman Abud dkk., The Bugis (Jakarta: Nalar bekerja sama Forum Jakarta-Paris, EFEO, 2005), h. 254. Bandingkan dengan Mursalim, "Tafsir Bahasa Bugis/Tafsir al-Qur'an al-Karim Karya Majelis Ulama Indonesia (MUI) Sulawesi Selatan; Kajian terhadap Pemikiran-Pemikirannya” Disertasi, (Jakarta: UIN Syarif Hidayatullah, 2008), h. 231-232.

${ }^{14}$ Mattulada, "Latoa; Suatu Lukisan terhadap Antropologi-Politik Orang Bugis", Disertasi, (Jakarta: Universitas Indonesia, 1975), h. 13. Lihat pula Mursalim, Tafsir Bahasa Bugis..., h. 232 . 
dapat diartikan "dua yang senantiasa dijadikan pagar ( untuk menyelematkan diri), yaitu kesucian dan kejujuran". ${ }^{15}$ Kesucian yang dimaksud dalam hal ini adalah suci dalam hati dan tindakan. Suci dalam jiwa ${ }^{16}$ itu mengandung arti adanya ketulusan hati, kebeningan jiwa, mindset positif, tidak iri, dan sebagainya. Sedangkan suci dalam tindakan adalah menjaga hal-hal yang memalukan, baik dalam takaran budaya maupun perspektif agama. Dalam konteks penyelenggaraan kemasyarakatan dan ketatanegaraan "paccing" bermakna tidak melakukan korupsi dan bentuk kecurangan lainnya, sebab hal itu merupakan kejahatan yang bertentangan dengan prinsip kejujuran (lempu'). Jika kejujuran telah hilang maka siri' (harga diri) juga akan hilang.

Ketika Tociung, Cendikiawan Luwu, diminta nasihatnya oleh calon raja (datu) Soppeng, La Manussa’ Toakkareng, Tociung menyatakan:

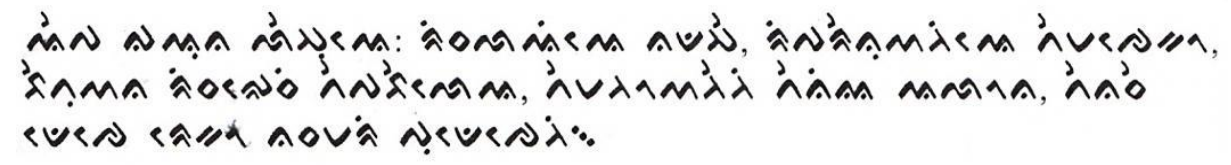

Terjemahan:“Ada empat inti perbuatan jujur: Memaafkan kesalahan orang lain padanya, jujur dalam menerima amanah, artinya tidak berkhianat, tidak serakah dan tidak mengambil yang bukan haknya, ia tidak menganggap kebaikan kecuali baik juga bagi orang lain". ${ }^{17}$

Sejalan dengan pengertian di atas, Kajaolaliddong, cendikiawan Bone, menjelaskan kejujuran ketika ditanya oleh Raja Bone mengenai pokok-pokok keilmuan. Apa saksinya atau bukti kejujuran? “Seruan ya Ampone!” Apa yang diserukan ya Kajao? "Adapun yang diserukan ialah:

15 Salah satu keunikan bahasa Lontarak adalah dalam satu kata bisa saja memiliki arti yang sangat jauh berbeda dengan arti lainnya demikian juga bacaanya, karena di dalam penulisannya tidak memiliki tanda-tanda khusus, misalnya tasydîd (huruf doble) dan mâddah (panjang).

16 Nilai paccing (kesucian jiwa) sejalan dengan Qs. al-Syams/91: 7-9: "Demi jiwa serta penyempurnaannya (ciptaannya), Maka Allah mengilhamkan kepada jiwa itu (jalan) kefasikan dan ketakwaannya.Sesungguhnya beruntunglah orang yang mensucikan jiwa itu".

${ }^{17}$ A. Rahman Rahim, Nilai-Nilai Utama Kebudayaan Bugis, (Yogyakarta: Penerbit Ombak, 2011), h. 119-120. Ia mengutip dari Lontarak kepunyaan H. Andi Mappasala. Kalimat “...tennaseng deceng rekko nassamarini pudeceng" ini agaknya rancu. Sesuai dengan artinya "tidak memandang kebaikan kalau hanya untuk dirinya, baginya baru dikatakan kebaikan kalau bisa dinikmati bersama" mestinya bunyinya kurang lebih demikian "...tennaseng deceng rekko- deceng rialemi, iyapa nariasenng deceng rekko- nassamarini pudeceng. 


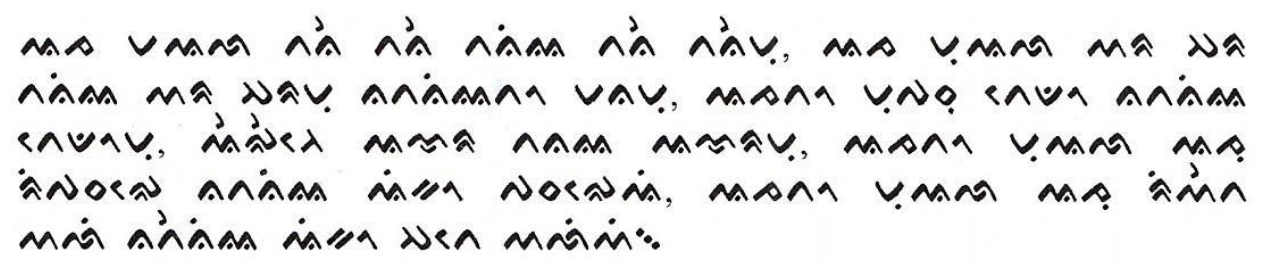

Terjemahan:"Jangan mengambil tanaman yang bukan tanamanmu, jangan mengambil barang-barang yang bukan barang-barangmu, bukan juga pusakamu; jangan mengeluarkan kerbau (dari kandangnya) yang bukan kerbaumu, juga kuda yang bukan kudamu, jangan ambil kayu yang disandarkan, bukan engkau yang menyandarkan, jangan juga kayu yang sudah ditetak ujung pangkalnya, yang bukan engkau yang menetaknya."

Pesan ini menunjukkan komitmen kejujuran, yakni tidak mengambil hak orang lain. Jika seseorang sebagai aparat pemerintah, ia tidak mengambil hak rakyat melalui korupsi dan penyalahgunaan wewenang dan jabatan. Di dalam petuah Bugis di atas, kayu yang sudah dipotong pertanda ada yang punya. Kalau yang tersimpan di pinggir jalan saja dipesankan agar tidak diambil, apalagi yang jelas dijaga di dalam pagar. Pesan ini diungkapkan dalam bahasa Bugis dengan sangat halus dan mengandung kedalaman makna, yakni komitmen kejujuran.

Kejujuran (lempu') adalah harga dirinya dan bentuk pengejawantahan rasa malu ${ }^{18}$ (siri'), sehingga jika ia kehilangan kejujuran berarti kehilangan kepercayaan dan pada saat yang sama harga dirinya ikut lenyap. Sebaliknya, jika kejujuran terpelihara dengan baik, maka nilai dan harga diri serta martabat insaniyahnya ikut terpelihara dengan baik pula. Dalam nilai-nilai utama kebudayaan Bugis, kesesuaian antara kata dan perbuatan disebut taro ada taro gau atau iya ada iya gau (antara kata dan perbuatan sama). "Ada" (kata atau ucapan) adalah pegangan, ketika ia diucapkan maka bukan lagi milik yang mengucapkan, sehingga berhati-hati dalam mengucapkan sesuatu kata. Secara etimologis, amaccang berasal dari acca. Dalam bahasa Bugis acca semakna dengan 'cendikia', yaitu pandai atau pintar. Acca ini lebih kepada makna kecerdasan yang positif, dan tidak sebaliknya. To acca adalah orang

${ }^{18}$ Bandingkan dengan Azhar Arsyad, "Pendidikan Karakter: al-Qwl al-Qadîm wa al-Qawl al-Jadîd”' Jurnal al- 'Ulûm, Jurnal Studi-Studi Islam, Vol. 13, No. 1, IAIN Sultan Amai Gorontalo, 2013, h. 58. 
mempunyai kearifan. Acca adalah prilaku baik cara berpikir maupun cara bertindak dapat menjadi pertimbangan yang arif. ${ }^{19}$ Jadi, acca bukan latar belakang pendidikan formal, melainkan nilai-nilai kearifan yang menghiasi cara berpikirnya dan bertindaknya. Tidak disebut pula To Acca (cendikia) kalau tidak jujur. Kalau ada orang berilmu tetapi tidak jujur, tidak pemaaf, serakah, mengambil yang bukan haknya maka hakikatnya ia tidak pandai (bukan To Acca). Prilaku To Acca (cendikiawan) terpancar dari setiap tutur kata yang benar dan santun, prilaku jujur, pemaaf, tidak serakah, dan lain-lain. Kecendikiaan seseorang tidak diukur dari gelar akademik, melainkan kecerdasan/kecendikiaan mesti dipaket antara teori (kognitif) dan prakteknya. Kejujuran dan kecendikiaan adalah nilai utama budaya orang Bugis yang saling berhubungan. Yang dinamakan amaccang adalah tidak ada yang sulit dilaksanakan, tidak ada pembicaraan yang sulit disambut, dengan kata-kata yang baik dan lemah-lembut lagi percaya kepada sesama manusia. Yang dinamakan jujur ialah perbuatan baik, pikiran benar, tingkah laku sopan lagi takut kepada Tuhan. ${ }^{20}$ Pendidikan yang berhasil membentuk kecendikiaan adalah pendidikan yang mampu menanamkan kepribadian yang santun, prilaku jujur, pemaaf, tidak serakah, senang menolong sesama. Kejujuran akan melahirkan karakter yang mandiri, kuat, dan bermartabat, sedangkan kecurangan melahirkan karakter yang lemah, curang, dan khianat. Unsur-unsur dalam nilai amaccang seperti kepribadian yang santun, prilaku jujur, pemaaf, tidak serakah, senang menolong sesama merupakan nilai kearifan lokal sekaligus nilai-nilai qurani.

Kepatutan, kepantasan, kelayakan dalam bahasa Bugis disebut asitinajang. Kata ini berasal dari tinaja yang berarti cocok, sesuai, pantas atau patut. Lontarak mengajarkan budaya sitinaja dengan mengatakan: "Duduki kedudukanmu, tempati tempatmu."21 Ade' Wari (adat perbedaan) dalam

\footnotetext{
${ }^{19}$ A. Rahman Rahim, Nilai-Nilai Utama..., h. 126.

${ }^{20}$ A Hasan Machmud, Silasa, hlm. 36, butir 31. Bandingkan dengan Waspada Santing dkk., dalam Chairuddin B, Refleksi 75 Tahun Prof. Dr. Hj. Andi Rasdiyanah; Meneguhkan Eksistensi Alauddin, (Makassar; Pustaka Al-Zikra, 2010), h. 196-199.
}

${ }^{21}$ A. Rahman Rahim, Nilai-Nilai Utama... h. 129. 
budaya Bugis pada prinsipnya mengatur segala sesuatu agar berada pada tempatnya atau mappasitinaja. Kewajiban yang dibaktikan dengan memperoleh hak yang sepadan adalah sesuatu perbuatan yang patut, banyak atau sedikit, tidak dipersoalkan dalam konsep sitinaja. Hal ini sesuai dengan petuah: "Alai cedde'e risesena engkai mappideceng, sampeangngi maegai risesena engkai makkasolang". ${ }^{22}$ "Ambillah yang sedikit jika yang sedikit itu mendatangkan kebaikan, dan tolaklah yang banyak apabila yang banyak itu mendatangkan kebinasaan/kerusakan". "Prinsip asitinajang adalah sitinajai resona na appoleangenna "sesuainya antara pekerjaannya dengan pendapatannya.

Dalam prinsip budaya orang Bugis - yang menghayati budayanya,memperoleh hasil harus sesuai dengan pekerjaannya, sesuai dengan tanggung jawabnya. Jadi, korupsi merupakan jalan pintas yang sangat tidak pantas (haram, ilegal), melanggar aturan, norma, sebab hal itu merugikan rakyat dan negara. Orang yang memperoleh hasil tidak sesuai dengan kerjanya itu tidak pantas (de' nasitinaja). Ukuran kepatutan itu bisa diukur dari aturan-aturan dan perundang-undangan yang berlaku, atau dalam takaran agama mengenai halal dan haram. Dalam tinjauan Islam, kejujuran adalah implementasi iman dan takwa yang hakiki kepada Allah Swt. Dalam konteks kehidupan bernegara, keimanan dan ketakwaan sesuai dengan sila "Ketuhanan yang Maha Esa" dan pasal 29 UUD 1945.

Asitinajang itu harus diajarkan dan dilatihkan kepada peserta didik agar tumbuh dalam prilaku yang layak dan wajar dalam takaran agama dan budaya. Takarannya senantiasa merujuk kepada aturan yang berlaku. Prilaku curang, contek merupakan sebuah bentuk kegagalan menanamkan kejujuran yang melahirkan prilaku yang tidak pantas dan bertentangan dengan nilai lempu'.

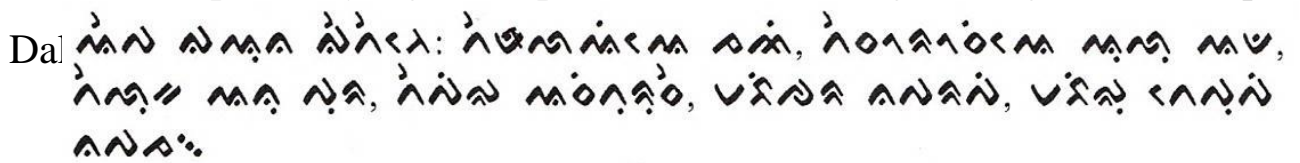

${ }^{22}$ A. Rahman Rahim, Nilai-Nilai Utama..., h. 130 dikutip dari A. Hasan Machmud, hlm. 76, butir 108. Korupsi, selain tidak pantas (de' nasitinaja), ia juga merusak (makkasolang), karena iitu korupsi bertentantangan dengan nilai budaya Bugis dan sangat memalukan. 
Prinsip keteguhan orang Bugis tetap pada asas atau setia pada keyakinan, kuat dan tangguh dalam pendirian, erat memegang sesuatu. Nilai kecendikiaan, dan nilai kepatutan, maka nilai keteguhan (agettengeng) ini terikat oleh nilai positif.

Terjemahan: Empat nilai keteguhan; pertama, tidak mengingkari janji, kedua, tidak menghianati kesepakatan, tidak membatalkan keputusan, ketiga, tidak mengubah keputusan, dan keempat, berbicara dan berbuat serta bila bekerja tidak berhenti sebelum rampung. ${ }^{23}$

Agettengeng (keteguhan) adalah sebuah prinsip keberanian menanggung resiko atas kejujuran, kebenaran, kepantasan, sehingga ia tidak akan mungkin goyah oleh godaan dan praktek transaksi untuk kepentingan semu. Keberanian (awaraning) kadang nyawa taruhannya, tetapi itulah harga diri (siri'). Pribahasa "lebih baik mati berkalang tanah daripada hidup bercermin bangkai" adalah sebuah pribahasa yang sesuai dengan prinsip siri' dan agettengeng. Sekali menduduki jabatan dan kewenangan, ia harus memberikan nilai manfaat dan maslahat bagi masyarakat tanpa membedakan (temmappasilaingeng). Keteguhan memegang prinsip kebenaran dan kebaikan harus ditanamkan kedalam jiwa peserta didik agar mereka memiliki mental yang kuat dan prinsip yang teguh dalam menghadapi berbagai tantangan di eranya masing-masing.

Prinsip masyarakat Bugis yang teguh mememegang nilai-nilai budayanya, kerja (reso) merupakan kehormatan diri (nilai siri'). Reso atau etos kerja, ditinjau dari agama dan budaya merupakan kunci meraih kesuksesan. Reso tidak dapat berdiri sendiri terpisahkan dari nilai-nilai lainnya. Nilai-nilai etos kerja atau reso berkaitan erat dengan nilai-nilai kejujuran (lempu'), kecendikiaan (amaccang), kepatutan (asitinajang), dan keteguhan (agettengeng). Bahkan, usaha dan kerja keras (reso) adalah kunci bagi pelaksanaan nilai-nilai lempu', acca, asitinajang, getteng, sebab nilai-nilai ini baru dapat berperan secara tepat guna dan berdaya guna apabila didukung oleh

${ }^{23}$ A. Rahman Rahim, Nilai-Nilai Utama..., h. 133. 
nilai-nilai usaha (reso). Dengan sendirinya, nilai usaha ini pun tegak di atas landasan nilai-nilai tersebut. ${ }^{24}$

Ajaran Lontarak mencela orang yang pemalas, tidak ada usahanya, dan hanya menghabiskan waktunya. ${ }^{25}$ Nilai-nilai dan prinsip tersebut merupakan kunci keberhasilan orang Bugis bahkan setiap orang. Selama berpijak pada nilai-nilai tersebut, serta menjunjung tingginya akan melahirkan kepercayaan masyarakat (public trust), sehingga mereka dapat eksis dimana pun berada. Sebalinya, ketidakjujuran hanyalah akan melahirkan ketidakpercayaan (distrust) bagi masyarakat, begitu juga halnya kemalasan. Ada empat hal yang diperintahkan oleh Lontarak bagi pengusaha atau peniaga; yaitu pertama, kejujuran (lempu'), karena dengannya akan menimbulkan kepercayaan; kedua, pergaulan (assisompungeng) atau silaturrahmi, link, karena pergaulan yang baik akan mengembangkan usaha, ketiga, kecendikiaan (amaccang), karena ia akan memperbaiki pengelolaan dan ketatalaksanaan, dan keempat, modal, karena inilah yang menggerakkan usaha. ${ }^{26}$ Usaha (reso) merupakan kunci kesuksesan hidup bukan hanya bagi orang Bugis, melainkan bagi semua orang di dunia. Etos kerja merupakan keharusan universal, tidak hanya terbatas pada agama dan budaya tertentu saja. Kerja keras saja tidak cukup tanpa rasa kebersamaan. Dalam masyarakat Bugis dikenal istilah budaya sibaliperri (saling menolong) sipurepo' (sepenanggungan). Paradigma kompetisi tersebut sebaiknya diubah menjadi paradigma kolaborasi. Sebab, kompetisi tidak jarang mengakibatkan adanya super power dan ada yang tidak berdaya. Ini berarti muncul kesenjangan yang tajam. Sedangkan paradigma kolaborasi membentuk prilaku senantiasa dalam kebersamaan, saling menolong, sepenanggungan. Inilah yang disebut budaya Pacce (solidaritas yang tinggi) atau sibaliperri' atau sipurepo'.

${ }^{24}$ Bandingkan dengan A. Rahman Rahim, Nilai-Nilai Utama..., h. 136.

${ }^{25}$ Dalam al-Qur'an terdapat sejumlah ayat yang menghargai orang-orang yang rajin bekerja dengan professional. Bekerja dalam Islam merupakan ibadah. Terdapat sejumlah hadis yang mencela orang malas, dan menghargai orang bekerja sebagai bentuk kesalehan. Bahkan, tangan di atas (pemberi) lebih baik daripada tangan di bawah (meminta dan mengharap pemberian orang lain).

${ }^{26}$ A. Rahman Rahim, Nilai-Nilai Utama ..., h. 137. 
Nilai-nilai utama tersebut dibingkai dengan prinsip yang disebut siri' (malu atau harga diri) yang merupakan prinsip utama masyarakat Bugis. Siri' pada mulanya mengandung makna yang berkonotasi posistif, tetapi jika tidak dibingkai dengan nilai-nilai luhur lainnya ia dapat pula berkonotasi negatif. ${ }^{27}$ Siri' seringkali dimaknai sebagai nilai bagi orang Bugis. Karena itu, jika seseorang melakukan hal-hal yang tidak baik, itu memalukan (mappakasisri'). Jika ia melakukan hal-hal yang jelek dan memalukan maka di saat itulah harga diri dan nilai kemanusiaannya turun. Sebaliknya, jika ia melakukan hal positif dan baik, di saat itulah ia menaikkan derajat kemanusiaannya sebagai orang Bugis.

Orang yang telanjang dari perasaan malu (siri') adalah telanjang dari aspek moralitas, dan oleh lontara' orang itu diserupakan dengan binatang. Binatang paling buruk adalah binatang yang kerjanya hanya melakukan kerusakan, menjengkelkan, menjijikkan, yakni tikus. Di sawah ia merusak tanaman (disebut hama padi), setelah dipanen dan disimpan di rakkiang rumah juga dirusak, selesai ditumbuk menjadi beras, sudah dimasak, tikus terus mempreteli. Nasi yang sudah dimakannya, dikencingi, diberaki, kemudian ia turun ke tanah dan di situ tahi pun dijilatnya, dinding dilobangi.

Jika melakukan yang menyerupai sifat tikus, kerjanya merusak sistem, melanggar aturan, mengacaukan kehidupan, mengumbar aib diri dan orang lain di saat itulah manusia jatuh harga diri dan wibawanya. Jika ia tidak melakukan hal-hal yang mengangkat nilai dan derajat kemanusiaannya, ia bagaikan tikus. Oleh karena itu, nilai siri' yang berkonotasi positif harus ditegakkan, sehingga tatanan kehidupan masyarakat menjadi lebih bermartabat dan memberikan nilai-nilai positif bagi kehidupan. Siri' sebagai harga diri, martabat, khususnya bagi masyarakat Bugis yang memelihara nilai-nilai luhur, dalam konteks Islam bahkan, siri' itu adalah bagian dari iman dan tidak ada iman bagi yang tidak punya rasa malu. Nilai siri' akan mendorong mereka menjadi pribadi-pribadi yang tangguh, pekerja keras, dan cerdas sehingga tidak

${ }^{27}$ A. Rahman Rahim, Nilai-Nilai Utama ...., h. 139-140. 
menjadi beban bagi orang lain. Dengan prinsip reso (usaha), mereka akan tumbuh menjadi pribadi mandiri dan pantang "menganggur" karena hal tersebut tidak sesuai dengan prinsip yang mereka anut. Orang Bugis mempunyai budaya pasompe' (perantau, hijrah). Dengan budaya ini orang Bugis memiliki jiwa pekerja keras.

\section{E. Kesimpulan}

Sila Ketuhanan yang Maha Esa dan Bhineka Tungal Ika meniscayakan pendidikan berbasis pada nilai-nilai agama dan budaya. Sebagai garda terdepan dalam rangka membangun karakter maka pendidikan harus mempu mentransfer dan menginternalisasi nilai-nilai luhur yang bersumber dari nilainilai agama dan nilai-nilai luhur budaya yang relevan. Dalam rangka mengatasi berbagai krisis, pendidikan harus mampu sejak dini melakukan internalisasi nilai-nilai luhur yang bersumber dari ajaran agama dan nilai-nilai kearifan budaya. Nilai-nilai kearifan budaya lokal sejatinya diperkenalkan dan ditanamkan dalam kesadaran peserta didik, sehingga nilai-nilai luhur itu tetap eksis dan membudaya dalam prilakunya. Kearifan lokal (al-'urf) disamping diapresiasi oleh Islam. Nilai-nilai luhur ajaran Islam mengenai integritas dan kejujuran tidak disangsikan lagi sebagai kebenaran universal yang bersumber dari Tuhan, sehingga kejujuran merupakan kebutuhan dasar (basic need) manusia secara keseluruhan tanpa dibatasi oleh latar belakang agama dan kepercayaan, suku, serta budaya. Alquran mengisyaratkan bahwa penanaman nilai-nilai kejujuran merupakan ranah afektif sebagai bagian integral dalam pendidikan yang menjadi kunci membangun karakter dan integritas peserta didik yang kelak memegang amanah publik atau menjadi warga Negara yang berkarakter baik. Jadi, pemberian porsi terhadap aspek kognitif -intelektual secara tidak seimbang dengan aspek emosional dan spiritual berdampak buruk bagi penyelenggaraan pemerintahan.

\section{Daftar Pustaka}

Abdullah, Hamid, Manusia Bugis-Makassar: Suatu Tinjauan Historis terhadap Pola Tingkah Laku dan Pandangan Hidup Bugis-Makassar, Jakarta: Inti Dayu, 1985. 
Abdullah. Amin, "Pendidikan Islam dan Tantangan Modernitas", Jurnal Pendidikan Lentera, Makassar: Fakultas Tarbiyah IAIN Alauddin, 1998.

Arsyad, Azhar, "Pendidikan Karakter: al-Qwl al-Qadîm wa al-Qawl al-Jadîd" Jurnal al- 'Ulûm, Jurnal Studi-Studi Islam, Vol. 13, No. 1, IAIN Sultan Amai Gorontalo, 2013, h. 58.

Arsyad, Azhar, "Universitas Islam: Integrasi dan Interkoneksitas Sains dan Ilmu Agama Menuju Peradaban Islam Universal”, Junal Tsaqâfah, Jurnal Ilmu Pengetahuan dan Kebudayaan Islam, Institut Studi Islam Darussalam (ISID) Pondok Modern Darussalam Gontor, Indonesia, Vol. 2. No. 2, 2006.

Baco, AG.H. Muh Sanusi, Ketua Umum Majelis Ulama Indonesia Sulawesi Selatan, Taushiyah, dalam rangka Diskusi tentang Sertifikasi Dai yang di Prakarsai oleh Pengurus NU Wilayah Sulsel, Makassar, 19 Maret 2015.

Mattulada, "Latoa; Suatu Lukisan terhadap Antropologi-Politik Orang Bugis", Disertasi, Jakarta: Universitas Indonesia, 1975.

Mattulada, "Sulawesi Selatan Pra Islam", dalam Bultetin Yaperna, No. 12, tahun III.

Mursalim, "Tafsir Bahasa Bugis/Tafsir Alquran al-Karim Karya Majelis Ulama Indonesia (MUI) Sulawesi Selatan; Kajian terhadap PemikiranPemikirannya”, Disertasi, Jakarta: UIN Syarif Hidayatullah, 2008.

Pelras, Christian, "Manusia Bugis”. Terj. Abdul Rahman Abud dkk., The Bugis, Jakarta: Nalar bekerja sama Forum Jakarta-Paris, EFEO, 2005.

Pramudya, Wahyu, "Pluralitas Agama: Tantangan Baru bagi Pendidikan Keagamaan di Indonesia", Veritas: Jurnal Teologi dan Pelayanan, Vol. 6, No. 2, Oktober 2005.

Rahim, A. Rahman, Nilai-Nilai Utama Kebudayaan Bugis, Yogyakarta: Ombak, 2011.

Riekerk, G.H.M, "Lahirnya Kedatuan Tomanurung”, Kutipan Ceramah, Fakultas Hukum Universitas Hasanuddin Ujung Pandang, 13 Agustus 1969.

Santing, Waspada, dkk. Refleksi 75 Tahun Prof. Dr. Hj. Andi Rasdiyanah; Meneguhkan Eksistensi Alauddin, Makassar; Pustaka Al-Zikra, 2010.

Shihab, M. Quraish, "Pendidikan Nilai untuk Pembentukan Sikap dan Prilaku", Jurnal Pendidikan, Ujung Pandang: Lentera Fak. Tarbiyah IAIN Alauddin 1997.

Sultan, Muhammad Sayyid, Buhûuts fî al-Tarbiyah fî̀ al-Tarbiyah al-Islâmiyyah, Kairo: Dâr al-Ma'ârif, 1979. 
Tim Penyusun, Mengembangkan Budaya Kerja Melalui Pengawasan dengan Pendekatan Agama, Jakarta: Itjen Kementerian Agama RI., 2011.

Yusuf, Muhammad, Tafsir Ayat-Ayat Pendidikan dengan Metode Semi Tematik dan Tematik, Makassar:Alauddin University Press, 2014. 